Article

\title{
Assessment of Waterfront Office Redevelopment Plan on Optimal Building Arrangements with Rooftop Photovoltaics: A Case Study for Shinagawa, Tokyo
}

\author{
Younghun Choi ${ }^{1}$, Takuro Kobashi ${ }^{1, * \mathbb{D}}$, Yoshiki Yamagata ${ }^{1}$ and Akito Murayama ${ }^{2} \mathbb{D}$ \\ 1 Center for Global Environment Research, National Institute for Environment Studies, \\ Tsukuba 305-8056, Japan; zlzlaga@gmail.com (Y.C.); yamagata@sdm.keio.ac.jp (Y.Y.) \\ 2 Department of Urban Engineering, School of Engineering, The University of Tokyo, Tokyo 113-8656, Japan; \\ murayama@up.t.u-tokyo.ac.jp \\ * Correspondence: kobashi.takuro@nies.go.jp
}

check for updates

Citation: Choi, Y.; Kobashi, T.;

Yamagata, Y.; Murayama, A. Assessment of Waterfront Office Redevelopment Plan on Optimal Building Arrangements with Rooftop Photovoltaics: A Case Study for Shinagawa, Tokyo. Energies 2022, 15, 883. https://doi.org/10.3390/ en15030883

Academic Editor: Wilfried van Sark

Received: 3 January 2022

Accepted: 24 January 2022

Published: 26 January 2022

Publisher's Note: MDPI stays neutral with regard to jurisdictional claims in published maps and institutional affiliations.

Copyright: (c) 2022 by the authors. Licensee MDPI, Basel, Switzerland. This article is an open access article distributed under the terms and conditions of the Creative Commons Attribution (CC BY) license (https:// creativecommons.org/licenses/by/ $4.0 /)$.

\begin{abstract}
Designing waterfront redevelopment generally focuses on attractiveness, leisure, and beauty, resulting in various types of building and block shapes with limited considerations on environmental aspects. However, increasing climate change impacts necessitate these buildings to be sustainable, resilient, and zero $\mathrm{CO}_{2}$ emissions. By producing five scenarios (plus existing buildings) with constant floor areas, we investigated how buildings and district forms with building integrated photovoltaics (BIPV) affect energy consumption and production, self-sufficiency, $\mathrm{CO}_{2}$ emission, and energy costs in the context of waterfront redevelopment in Tokyo. From estimated hourly electricity demands of the buildings, techno-economic analyses were conducted for rooftop PV systems for 2018 and 2030 with declining costs of rooftop PV systems. We found that environmental building designs with rooftop PV system are increasingly economical in Tokyo with $\mathrm{CO}_{2}$ emission reduction of 2-9\% that depends on rooftop sizes. Payback periods drop from 14 years in 2018 to 6 years in 2030. Toward net-zero $\mathrm{CO}_{2}$ emissions by 2050, immediate actions are necessary to install rooftop PVs on existing and new buildings with energy efficiency improvements by construction industry and building owners. To facilitate such actions, national and local governments need to adopt appropriate policies.
\end{abstract}

Keywords: building; electricity demand; photovoltaics; techno-economic analysis; urban decarbonization; $\mathrm{CO}_{2}$ emission

\section{Introduction}

About $75 \%$ of global power consumption and $60-70 \%$ of greenhouse gas emissions originate from cities [1,2]. However, as the center of economic competitiveness and innovation, cities are also the sources of solutions [2,3]. Smart city is one of the necessary ingredients to urban sustainability contributing on recent urban challenges such as rapid expansion of urban population and decarbonization. Increasing digitization, development of Information and Communication Technology (ICT) and artificial intelligence (AI) is expected to play substantial roles on the development of decentralized urban power systems. In addition, declining costs of PV systems and EVs with increasingly tighter regulations are rapidly introducing these technologies into urban energy systems, which are integrated by the smart city technologies as distributed energy resources (DER) [4]. Studies indicated that rooftop PVs plus EVs as batteries can play substantial roles on urban decarbonization supplying up to $95 \%$ of affordable $\mathrm{CO}_{2}$-free electricity to urban dwellers in nine Japanese cities known as the SolarEV City concept $[5,6]$.

The Government of Japan announced that Japan aims to reach net-zero emission by 2050. Therefore, it is critical that all urban planning processes are to be assessed for future zero-emission. As Japan is constituted in four main islands with long coastlines, waterfront redevelopments are one of the higher priority policy options for many local governments 
to increase life quality of citizens and to attract tourists. As a consequence, many redevelopments of river or coastal sides are taking place [7-9] with benefits to improve economic values, environmental conditions, transport and social services, economic investment opportunities on currently degraded areas. At the time of rapid energy transition toward net-zero $\mathrm{CO}_{2}$ emission, this waterfront redevelopment planning must also integrate energy efficient building, block design, renewable energies such as tidal power, hydroelectric power, and solar power for their energy demands.

Energy demands for office buildings are created for various services such as lighting, space cooling and heating, office appliances, elevator, etc. Space heating and cooling demands (e.g., about $28 \%$ of the total office building energy demand in Japan [10]) are controlled by various factors such as building wall materials, efficiency of heating, ventilation, and air conditioning (HVAC) system, building shapes, and influence of shades by neighboring buildings. Therefore, to achieve efficient building energy systems, it is necessary to conduct energy assessments in the early planning phase of redevelopment with proper tools and methods [11-14]. In addition, retrofitting existing buildings needs to be considered for a rapid reduction of $\mathrm{CO}_{2}$ emission to reach net-zero emission by $2050[15,16]$. Expected rapid developments of PV technologies for the coming decades in terms of costs, efficiency, weights, and design, will provide unprecedented opportunities for these measures to be effective and beneficial to building owners.

Urban building energy modeling (UBEM) with three-dimensional (3D) representation are rapidly developing, and more and more applied to assess sustainable urban building forms [13,17-19]. For example, "Rhinoceros 3D" is a computer 3D graphics for computeraided design (CAD), and its plug-in Grasshopper is a visual programming environment. "Grasshopper" hosts various energy modeling tools such as Ladybugs and Honeybee, which further connect with a well-known building energy modeling tool such as "EnergyPlus". The analysis can be made for a building or building blocks in various resolution in time and space. As often hourly building energy demand is not publicly available owing to privacy, etc., these models are important for the assessments on the viability of variable renewable energies (VREs) such as BIPV in urban environments.

The tools have been utilized for various applications. Natanian et al. [12] analyzed various nearly zero energy building and district types between courtyard, scatter, slab, highrise, and courtyard in the hot/dry climate of Mediterranean. They found the courtyard typology performs to be the best option in terms of energy balance, but with less optimal performance in daylight utilization. Then, also Natanian et al. [20] introduced an energy and environmental quality evaluation workflow. Zhang et al. [21] compared energy demand and solar potentials of different block types in the hot and humid climate of Singapore. They found solar energy harvesting amount can increase up to $200 \%$ depending on block types with other variables constant except morphology. Chang et al. [14] investigated relationship between design parameters and urban performance parameters such as energy demands, solar harvesting potential, and sky view factor for university campus design in Shenzhen, China. They applied statistical approaches and identified optimal building coverage ratio and sky view factor.

Actual implementation of renewable energy projects such as BIPVs depends on financial merits in comparison to existing energy systems such as grid electricity [22]. Technoeconomic analyses can assess if a renewable energy project is viable considering the costs of technologies, discount rate, project period, degradation, electricity tariff, insolation changes, etc. [23]. As the cost of PV systems is expected to drop further [24], the viability of PV projects also improves significantly in the coming decades, increasing potentials of rooftops PVs [25]. Many studies have been conducted to test viability of rooftop PV systems coupled with battery and EV as battery for households [26-28]. For example, Lang et al. investigated residential and commercial buildings for viability using techno-economic analyses for Germany, Switzerland, and Austria [29]. They found that the rooftop PVs are already attractive to many buildings without subsidies. However, few studies have investigated impacts of building and block design for waterfront office redevelopment on 
energy demand, rooftop PV generation, $\mathrm{CO}_{2}$ emissions, considering declining costs of $\mathrm{PV}$ systems from 2018 to 2030.

In this study, we conducted environmental and energy analyses for waterfront office building redevelopment in Shinagawa, Tokyo, Japan as a test site (Figure 1). We produced five scenarios with different building and district forms (scenario 1-5) in comparison to existing buildings (scenario 0), which include nine buildings on average. Energy demands of buildings and rooftop PV generation in an hourly resolution are estimated for all the scenarios using "Rhinoceros 3D" and its plug-ins Grasshopper, etc., considering energy balance between in- and out-side of buildings with a weather file for 2018 as an input. Total floor areas of buildings and site area in all the scenarios are set constant for comparison purposes. Then, techno-economic analyses were conducted using System Advisor Model (SAM) [30] to assess the viability of rooftop PV systems for 2018 and 2030 to evaluate impacts of increasingly cheaper rooftop PV systems. Finally, environmental and energy indicators such as $\mathrm{CO}_{2}$ emission, self-sufficiency, self-consumption, and energy sufficiency were evaluated for each scenario as well as financial indicators (net present values (NPV), payback periods, and levelized costs of electricity (LCOE)).

\begin{tabular}{|c|c|c|c|}
\hline Input data & $\begin{array}{l}\text { GIS Data (existing building) } \\
\cdot \quad \text { Building footprint } \\
\cdot \quad \text { Height }\end{array}$ & - Weather file & $\begin{array}{l}\text { - Weather file } \\
\text { - Costs for } 2018 \text { and } 2030 \\
\text { - Discount rate, etc. }\end{array}$ \\
\hline \multicolumn{2}{|r|}{ \& } & Z & $\sqrt{2}$ \\
\hline Software & AreGIS & $\begin{array}{l}\text { Rhinoceros 3D } \\
\text { - Grasshopper } \\
\text { - EnergyPlus }\end{array}$ & System advisor model (SAM) \\
\hline \multicolumn{2}{|r|}{2} & 3 & 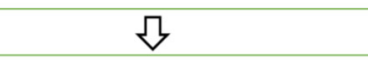 \\
\hline Analysis & Mapping & $\begin{array}{l}\text { Energy analysis for each } \\
\text { scenario } \\
\text { - Hourly demand } \\
\text { - Radiation potential on } \\
\text { building surface } \\
\text { - } 3 \text { D representation }\end{array}$ & $\begin{array}{l}\text { Techno-economic analysis on } \\
\text { roof-top PV system for } 2018 \text { and } \\
2030 \\
\text { - Cost saving } \\
\text { - Energy sufficiency } \\
\text { - Self-sufficiency } \\
\text { - Self-consumption }\end{array}$ \\
\hline
\end{tabular}

Figure 1. Evaluation workflow for waterfront building environmental energy analyses.

In the following Section 2, methodologies of the analyses were presented using Rhinoceros 3D, Grasshopper, and SAM. In the Section 3, estimated hourly energy demands for scenarios were presented, and various indicators were calculated and compared between scenarios. The implications of the results were discussed in the Section 4. Finally, we summarize and conclude our findings in the Section 5.

\section{Materials and Methods}

The test site, Shinagawa area $\left(35.6^{\circ} \mathrm{N}, 139.7^{\circ} \mathrm{W}\right)$ is located near Shinagawa Railway Station in Minato Wards, Tokyo, Japan. The Shinagawa Station is one of the busiest railway stations in Japan with annually 380,000 users. Land use of Shinagawa is divided by the Shinagawa Station. West side of the station is mainly for residential-oriented mixed-use area, and east side is office/industry-oriented mixed-use area where the test site is located. The test site (Figure 2) is near harbor along Tokyo Bay with canals going through the middle of the district. Currently, this waterfront area is not actively utilized as a recreation area considering their potentials. Shinagawa experiences maximum daily average temperature of $30{ }^{\circ} \mathrm{C}$ in summer and minimum temperature of $0{ }^{\circ} \mathrm{C}$ (Figure 3) with snow fall only occurring a few times a year. Coastal regions of Japan along Pacific Ocean including Shinagawa have generally fine weather in winter, as reflected in high quality PV generation but with shorter daytime (Figure 3). 


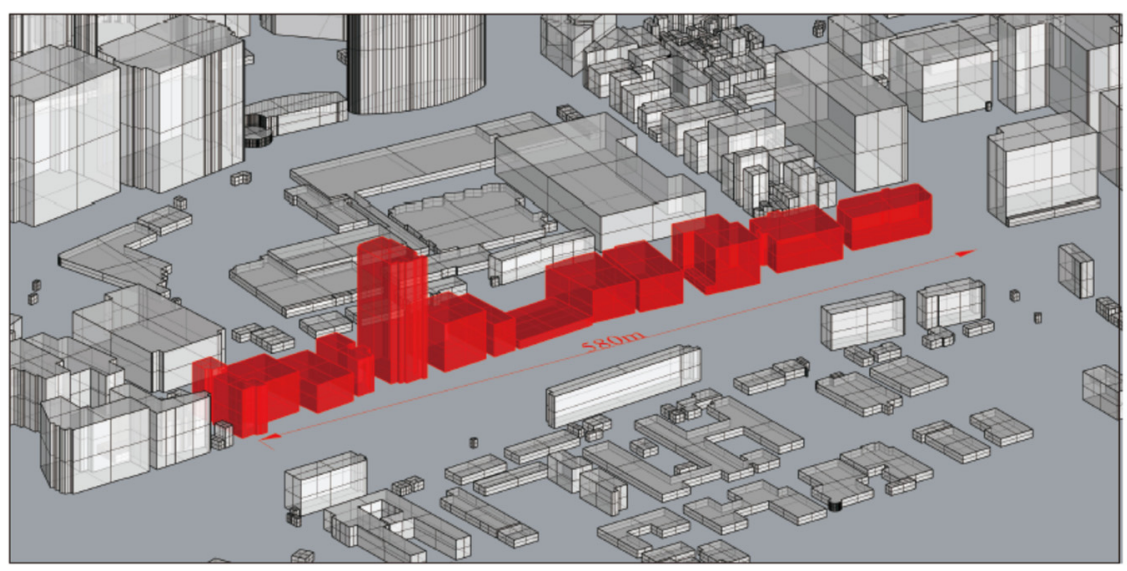

Figure 2. "Existing buildings" with surrounding buildings in Shinagawa area, Tokyo. Red colored buildings were analyzed as exiting buildings (scenario zero). It is noted that there is a canal in front of the existing buildings.
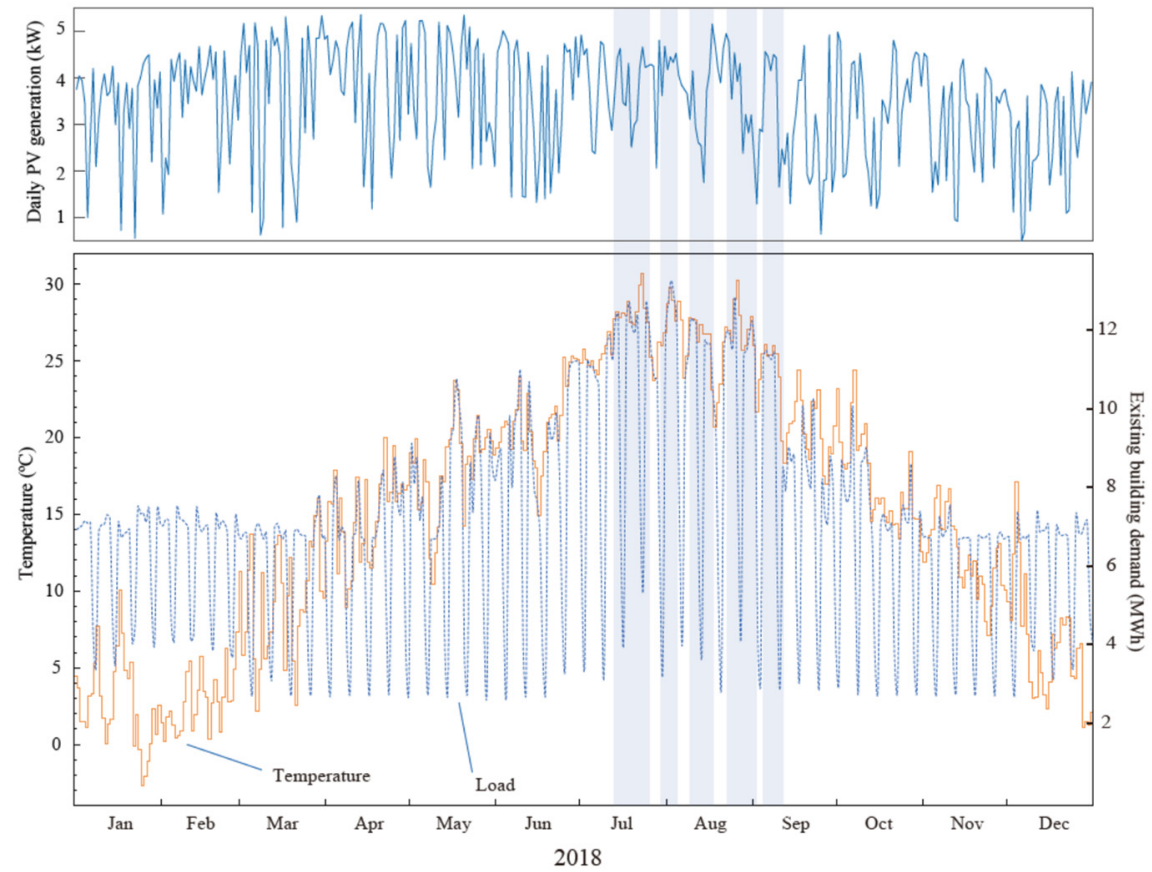

Figure 3. PV generation, daily outside temperature, and estimated demands of existing buildings for the test site in Shinagawa for 2018. Blue bands represent hot days with heightened cooling demand.

Environmental energy analyses were conducted as in a workflow chart in Figure 1. "ArcGIS", a Geographic Information System (GIS) program, was utilized to create GIS database and mapping [31]. Footprint and height data of buildings were obtained from publicly available dataset [32], and 3D polygons of buildings were produced by extruding foot-print areas with the corresponding heights of buildings (Figure 2). Then, the data was saved as a shapefile by "ArcGIS". "Rhinoceros 3D (version 6)" is a 3-dimensional computer aided design (3D CAD) software developed by Robert McNeel \& Associates (Seattle, WA, USA). "Rhinoceros 3D" and its plugin, "Grasshopper", provide various analysis tools (e.g., Ladybug and Honeybee for energy analyses) for building designers, allowing them to work with independently developed software such as "EnergyPlus", "Radiance", and "Daysim" [33]. "EnergyPlus" is a well-known program for whole building energy analyses developed by US Department of Energy (DOE) [34]. We used these programs to estimate hourly energy demand and PV generation potentials for buildings [14], considering building usage patterns, materials of walls, windows and rooftops, weather, and 
urban context such as shades of nearby buildings. All the specification is available in https: / / doi.org/10.17632/wfpkdc6rd7.1 (accessed on 5 January 2022) for Grasshopper. Accuracy of EnergyPlus has been tested and validated during its on-going development [35].

The shapefile was loaded into "Rhinceros 3D" (Figure 1). "Grasshopper" provides a platform to build sequences of energy analyses. A weather file (epw) is necessary to estimate hourly load and PV electricity generation. We used "SIREN" to produce a weather file for Shinagawa, Tokyo for 2018 [36]. "EnergyPlus", integrated within Ladybug, analyzes building hourly energy demands (heating, cooling, lighting, and appliances) considering the influences of shading from neighboring building. PV electricity generation was also calculated on the surface of buildings $\left(\mathrm{kWh} \cdot \mathrm{m}^{-2}\right)$ in hourly resolution (Figure 3), also considering shading (Figure 4). Annual radiation amounts on the surface of the buildings were calculated for each mesh with an average area of $8 \mathrm{~m}^{2}$ (Figure 4) Maximum annual radiation amount was calculated as $1383 \mathrm{kWh} \cdot \mathrm{m}^{-2}$ (Figure 4). Above-groundwindow/wall ratio for north, west, south, and east faced walls were set as $0.4,0.35,0.2$, 0.15 , respectively (Figure 5). Floor heights were set to $3 \mathrm{~m}$. Space heating and cooling demands were converted to electricity demand by coefficient of performance (COP) with the values of 2.27 and 2.51, respectively [37]. Owing to the rapid development of the building energy analyses tools, the analyses between the program are smoothly linked, and results can be readily projected as 3D building representation in Rhinoceros 3D (Figure 5). Grasshopper files for energy and radiation analyses with weather files are available as https:/ / doi.org/10.17632/wfpkdc6rd7.1 (accessed on 5 January 2022).

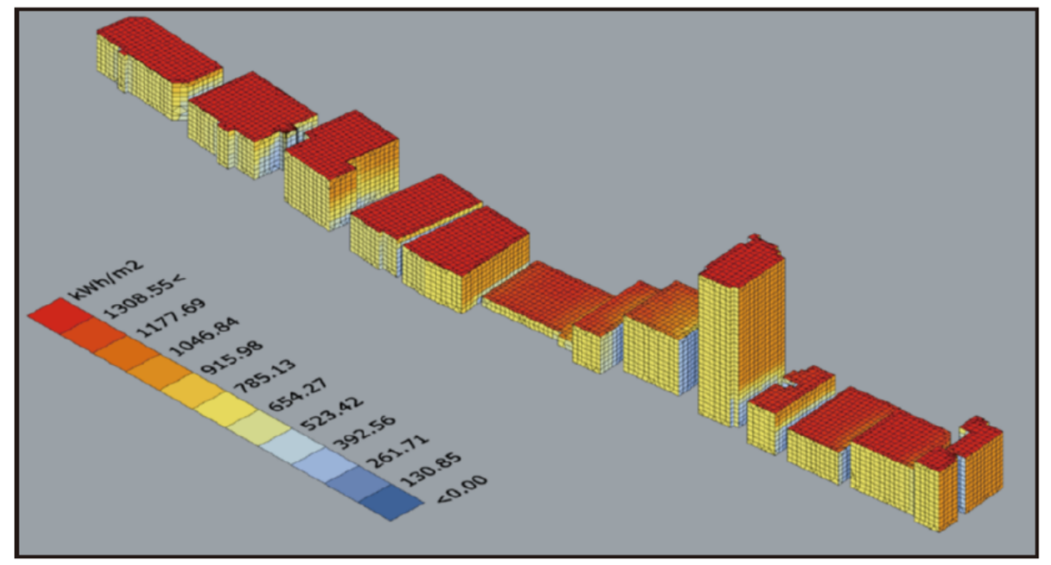

Figure 4. Annual radiation amount $\left(\mathrm{kWh} \cdot \mathrm{m}^{-2}\right)$ on the surfaces of the existing buildings calculated by Grasshopper. The direction of increasing radiation in the colorbar represents north.

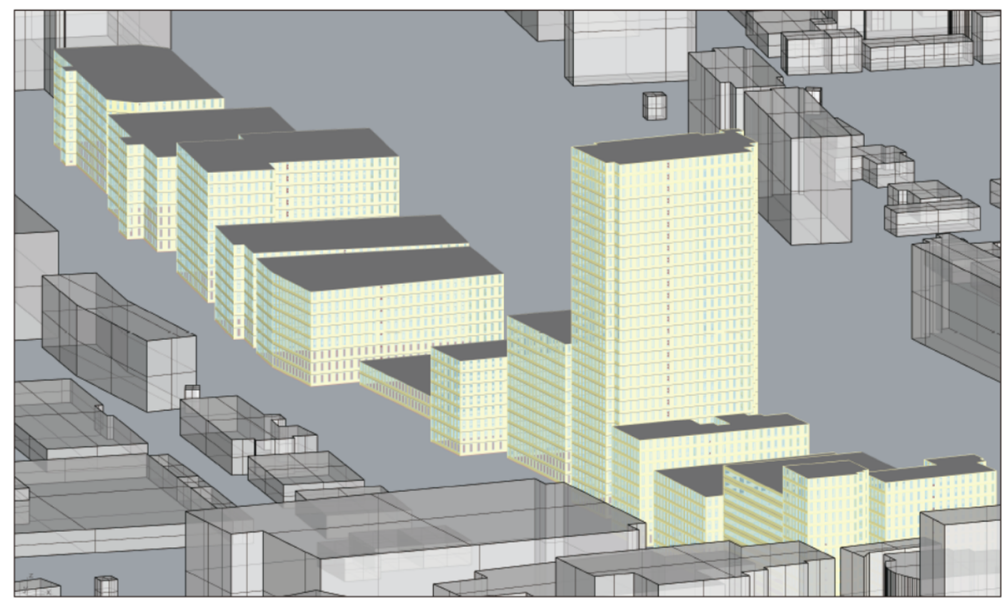

Figure 5. Existing buildings (yellow) with windows for the analyses. 
Techno-economic analyses evaluate the viability of renewable energy projects such as rooftop PV systems [25,28], comparing with existing energy systems. The analyses consider project periods, discount rates, costs of PV systems, degradation, various energy losses, tariffs, etc. [23]. To investigate the impacts of declining PV system costs, we conducted techno-economic analyses on rooftop PV systems on large office buildings for 2018 and 2030 (Table 1). The methods generally follow those of our earlier studies [5,6]. System Advisor Model (SAM) was used for our analyses. The software is publicly available and developed by National Renewable Energy Laboratory (NREL) of the U.S. DOE [30]. PV degradation rate is set to annually $0.5 \%$ and soiling on the surface of PV reduce generation by $5 \%$ [30]. Hourly energy demands of buildings were estimated using the aforementioned "Rhinoceros 3D". A weather file for 2018 was applied to SAM analyses. We used a project period of 25 years with a discount rate of $3 \%$ for the rooftop PV systems. Currency exchange rate of 110 yen $/ \$$ was used. Other parameters used for the analyses are listed in Table 1 . An electricity tariff price for high-voltage users was utilized for the analysis, which is cheaper than that for low voltage users (households, etc.) in Japan. SAM files with a weather file for the analyses were made available as https:/ / doi.org/10.17632/wfpkdc6rd7.1 (accessed on 5 January 2022).

Table 1. Parameters used for techno-economic analyses [5]. Small-scale PV system costs are for 2018 (2030), respectively. Maintenance costs for PV system include inverter replacements.

\begin{tabular}{cc} 
Items & $\mathbf{2 0 1 8 ( 2 0 3 0 )}$ \\
\hline Small-scale PV system cost $\left(\$ \mathrm{~kW}^{-1}\right)$ & $2.15(0.88)$ \\
PV system maintenance cost $\left(\$ \mathrm{~kW}^{-1} \cdot \mathrm{yr}^{-1}\right)$ & 31.4 \\
Electricity to buy $\left(\$ \mathrm{kWh}^{-1}\right)$ & 0.15 \\
Electricity to sell $(\$ \mathrm{kWh}-1)$ & 0.08 \\
PV tilt angle $(\mathrm{degree})$ & 30 \\
Grid emission factor $\left(\mathrm{kgCO}_{2} \cdot \mathrm{kWh}^{-1}\right)$ & 0.455 \\
\hline
\end{tabular}

We used net present values (NPVs) as a primary financial indicator and identified optimal PV capacity for each scenario using a function of SAM, "Parametrics". NPV of a PV project is a sum of discounted annual net saving over the project period including all the costs incurred (e.g., capital, and annual maintenance costs) [30,38].

Therefore, NPV is defined as:

$$
N P V(p, t)=\sum_{n=1}^{N} \frac{\operatorname{Cash} \operatorname{Flow}(p, n, t)}{\left(1+R_{d}\right)^{n}}-\operatorname{System} \operatorname{Cost}(p, t)
$$

where,

$$
\begin{aligned}
& p=\text { PV capacity }(\mathrm{kW}) \\
& t=\text { Project first year }(\mathrm{yr}) \\
& N=\text { Project period }(\mathrm{yr}) \\
& R_{d}=\text { Discount rate } \\
& \text { And }
\end{aligned}
$$

$$
\text { Cash Flow }(p, n, t)={\text { Electricity } \text { Cost }_{\text {Base }}(n, t)-\text { Electricity }_{\text {Cost }} \text { System }}(p, n, t)
$$

Electricity Cost $_{\text {base }}$ and Electricity Cost $_{\text {System }}$ are the costs of purchased grid electricity without and with PV systems, respectively. System Cost is the initial investment cost of PV systems [6]. 
Simple payback period (hereafter, payback period) is the time to recover the project cost of an investment, and can be expressed as the duration (e.g., years) from the initial investment to the time when the following condition is satisfied [38].

$$
\sum_{n=1}^{t} \Delta I_{n} \leq \sum_{n=1}^{t} \Delta S_{n}
$$

where $\Delta I$ is non discounted incremental investment costs (\$) and $\Delta S$ is non discounted sum value of the annual cash flows net annual costs (\$). $t$ represents the time when the condition is satisfied for the first time, payback period.

Levelized cost of electricity ( $L C O E)$ is a measure of the average net present cost of PV electricity generation for its lifetime. It is useful to compare various sources of energy. $\operatorname{LCOE}\left(\$ \mathrm{kWh}^{-1}\right)$ can be expressed as a following equation [30]:

$$
L C O E=\frac{-C_{0}-\sum_{n=1}^{N} \frac{C_{n}}{\left(1+R_{d}\right)^{n}}}{\sum_{n=1}^{N} \frac{Q_{n}}{\left(1+R_{d}\right)^{n}}}
$$

where $C_{0}$ is the initial investment cost $(\$), C_{n}$ is the annual project costs (\$) in year $n$, and $Q_{n}$ is electricity $(\mathrm{kWh})$ generated by the PV system in year $n$.

Analyzed results are also evaluated with following five environmental and energy indicators [6]. 1. Energy Sufficiency (ES) is how total PV generation can be compared to total annual demand. 2. Self-Sufficiency (SS) is how much PV generation can supply to local building demand considering hourly demand-supply balance. 3. Self-Consumption (SC) is how much PV generation can be consumed locally. 4. Cost Saving (CS) is how much energy costs can be saved by installing PV systems including capital and maintenance costs. 5. $\mathrm{CO}_{2}$ emission reduction by $\mathrm{PV}$ systems is calculated by comparing $\mathrm{CO}_{2}$ emission from gird electricity consumption before and after the system installation. All the indicators are expressed in percentage. Equations of the indicators can be expressed as:

$\mathrm{ES}=$ Total annual PV generation $(\mathrm{kWh}) /$ total annual demand $(\mathrm{kWh}) \times 100(\%)$

$\mathrm{SS}=$ Total PV electricity amount locally consumed / total annual demand $(\mathrm{kWh}) \times 100(\%)$

SC $=$ Total PV electricity amount locally consumed/total annual PV generation $(\mathrm{kWh}) \times 100(\%)$

$$
\text { Cost saving }=(\mathrm{NPV} / 25) /(\text { grid electricity cost })_{\text {base }} \times 100(\%)
$$

$\mathrm{CO}_{2}$ emission reduction $=\left\{1-\left(\mathrm{CO}_{2} \text { emission from grid electricity consumption }\right)_{\text {system }} /\left(\mathrm{CO}_{2}\right.\right.$ emission from grid electricity consumption $\left.)_{\text {base }}\right\} \times 100(\%)$

where $\mathrm{CO}_{2}$ emission from grid electricity consumption = total imported grid electricity $(\mathrm{kWh}) \times$ emission factor $\left(\mathrm{kgCO}_{2} \cdot \mathrm{kWh}^{-1}\right)$. Subscripts, "system" and "base" indicate building energy systems "with PV system" and "without PV system", respectively.

To evaluate various building shapes in a block for energy demand and PV generation, we produced five scenarios (scenario 1-5) in comparison to existing buildings (scenario 0) (Figure 6 and Table 2). Five scenarios are characterized by "Low-rise", "High-rise", "Center corridor", "Courtyard", and "Korean style". We set building widths in a range from $15 \mathrm{~m}$ to $50 \mathrm{~m}$ following general building shapes in the area. The "Low-rise" buildings (scenario 1) give pedestrian continuity along the front street. Therefore, they have advantages for small shops. "High-rise" buildings (scenario 2) are more independent to other buildings, which tends to foster unique identity to represent one company or residential buildings. Buildings with the "center corridor" (scenario 3) have a common open space between buildings. The open spaces around the buildings offer places for many community activities to workers, 
shops, and offices. "Courtyard" style (scenario 4) has similar shape as Scenario 3, but it is a typical courtyard type in Europe. Korean style (scenario 5) was adopted from building arrangements from Cheongye river, Seoul, South Korea, which is a well-known redeveloped waterfront area.
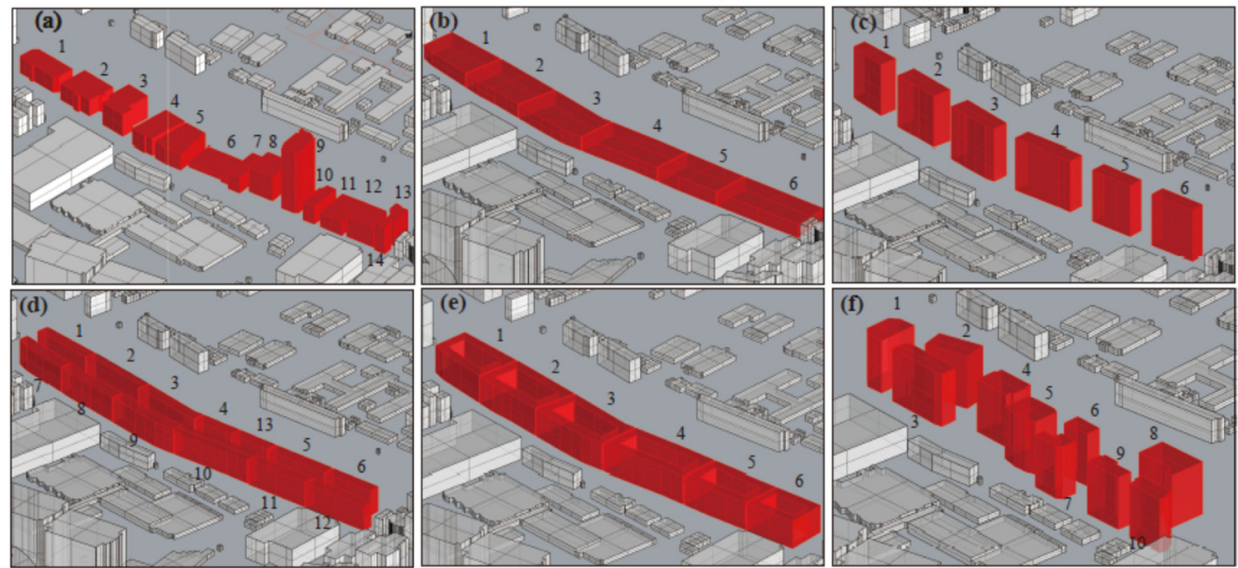

Figure 6. Existing buildings and five scenarios. (a) Scenario 0: existing buildings, (b) Scenario 1, (c) Scenario 2, (d) Scenario 3, (e) Scenario 4, and (f) Scenario 5. All the scenarios have the same FAR. Numbers next to buildings are building identification numbers.

Table 2. Characteristics of district scenarios. For the calculation of "surface area/volume", "aboveground surface area" was used. Numbers in parentheses were calculated by standard deviations divided by averages. See also Figure 5 for 3D building representation of the scenarios. Bldg. is an abbreviation for building.

\begin{tabular}{|c|c|c|c|c|c|c|c|c|}
\hline Scenario Number & 0 & 1 & 2 & 3 & 4 & 5 & & \\
\hline Character & Existing & Low-Rise & High-Rise & $\begin{array}{l}\text { Center } \\
\text { Corridor }\end{array}$ & Courtyard & $\begin{array}{c}\text { Korean } \\
\text { Style }\end{array}$ & Average & Deviation \\
\hline Number of bldgs. & 14 & 6 & 6 & 13 & 6 & 10 & 9 & $4(40 \%)$ \\
\hline Average bldg. height & 27 & 18 & 66 & 33 & 33 & 54 & 39 & $18(46 \%)$ \\
\hline Average number of floors & 9 & 6 & 22 & 11 & 11 & 18 & 13 & $6(46 \%)$ \\
\hline Floor area $\left(\mathrm{m}^{2}\right)$ & 185,000 & 185,000 & 185,000 & 185,000 & 185,000 & 185,000 & 185,000 & $0(0 \%)$ \\
\hline FAR $(\%)$ & 400 & 400 & 400 & 400 & 400 & 400 & 400 & $0(0 \%)$ \\
\hline BCR $(\%)$ & 44 & 67 & 18 & 36 & 36 & 22 & 37 & $17(46 \%)$ \\
\hline Total bldg. volume $\left(\mathrm{m}^{3}\right)$ & 555,000 & 555,000 & 555,000 & 555,000 & 555,000 & 555,000 & 555,000 & $0(0 \%)$ \\
\hline Total surface area $\left(\mathrm{m}^{2}\right)$ & 106,000 & 94,000 & 85,000 & 121,000 & 128,000 & 94,000 & 105,000 & $17,000(16 \%)$ \\
\hline Above-ground surface area $\left(\mathrm{m}^{2}\right)$ & 86,000 & 64,000 & 77,000 & 104,000 & 111,000 & 84,000 & 87,000 & $17,000(20 \%)$ \\
\hline Surface area/volume $\left(\mathrm{m}^{-1}\right)$ & 0.15 & 0.11 & 0.14 & 0.19 & 0.20 & 0.15 & 0.16 & $0.03(20 \%)$ \\
\hline Total rooftop area $\left(\mathrm{m}^{2}\right)$ & 20,200 & 30,800 & 8400 & 16,800 & 16,800 & 10,300 & 17,200 & $8000(46 \%)$ \\
\hline Total rooftop PV capacity $(\mathrm{kW})$ & 2890 & 4400 & 1200 & 2400 & 2400 & 1470 & 2460 & $1140(46 \%)$ \\
\hline
\end{tabular}

In the following energy modeling, it is assumed that all the buildings in the scenarios are set to be used as "office" for EnergyPlus. The analyses were conducted in an hourly resolution with weather information in 2018 for Shinagawa (Figure 3). To compare various building morphology in comparison to existing buildings, floor area ratio $(F A R)$ is set as a control variable. FAR is used to regulate building volumes and thus number of people in the districts or cities, which is inherently relate to necessary sizes of public services and goods such as water-sewer, road services, sun light availability, openness, and noises in the cities [39]. FAR is defined as:

$$
\text { FAR }(\%)=\text { total floor area/site area } \times 100
$$

As the site area $\left(46,250 \mathrm{~m}^{2}\right)$ is common for all the scenarios, the total floor areas of buildings in the scenarios are also constant (Table 2). This results in total building volumes 
to be the same for all the scenarios (Table 2). Another important building indicator to regulate building forms, "building coverage ratio $(B C R)$ " is defined as:

$$
B C R(\%)=\text { building area/site area } \times 100
$$

Along with the $F A R, B C R$ controls the shape and heights of buildings as well as occupied area by buildings in the site [40]. It is known that controlling $B C R$ is an important policy measure to prevent spreading of fire. $B C R$ varies between the scenarios from $18 \%$ to $67 \%$ (Table 2). Total surface areas above ground varies between the scenarios by $20 \%$. Surface area to volume ratio of buildings, which is an important indicator for energy balance of buildings, also varies by $20 \%$ among the scenarios (Table 2). Total rooftop areas vary by $46 \%$ between the scenarios (Table 2). $70 \%$ of the total rooftop area is considered to be available for PV installation as a PV panel with $20 \%$ efficiency needs areas of about $5 \mathrm{~m}^{2}$ plus an additional $2 \mathrm{~m}^{2}$ for management or shaded areas, etc. Thus, $7 \mathrm{~m}^{2} \cdot \mathrm{kW}^{-1}$ is used as a coefficient to calculate maximum rooftop PV capacity for each scenario (Table 2).

\section{Results}

\subsection{Building Energy Demands}

Estimated energy demands for buildings include interior lighting, interior electric equipment, space heating, and space cooling with typical office use activity in an hourly resolution. Interior equipment consumes the largest amount of electricity by $68 \%$ of the total, and lighting is $12 \%$ (Table 3). In addition, space heating and cooling are $2 \%$ and $18 \%$, respectively. Demands for lighting and interior equipment are constant among the scenarios (Table 3) as they are generally functions of floor area. Space heating, which shows the largest variability ( $13 \%$ of average) between the scenarios, has significant correlation with surface area/volume ratio, explaining $97 \%$ of variance (Figure 7 ). Space cooling, although much smaller variability $(0.8 \%$ of average), has significant correction with building height or number of floors (Table 3, Figure 7). Little variability of space cooling among the scenarios indicate that floor space or volume of building (set constant in this study) is the most important factor, and surface area-volume ratio has little impacts on space cooling. Unit floor electricity consumptions $\left(\mathrm{kWh} \cdot \mathrm{m}^{-2}\right)$ are generally consistent with available observed data of $290 \mathrm{kWh} \cdot \mathrm{m}^{-2}$ for office building electricity consumption for 2019-2020 [41]. Slightly older data of 2014 shows a larger average value of $389 \mathrm{kWh} \cdot \mathrm{m}^{-2}$ for office buildings in Kanto area [42].

Table 3. Calculated building energy demands for the scenarios. Parentheses at average section represent percentages of demand components to the total demand. Parentheses at standard deviation section represent percentages of standard deviation divided by averages.

\begin{tabular}{|c|c|c|c|c|c|c|c|c|}
\hline Scenario Number & 0 & 1 & 2 & 3 & 4 & 5 & & \\
\hline Name & Existing & Low-Rise & High-Rise & $\begin{array}{l}\text { Center- } \\
\text { Corridor }\end{array}$ & Courtyard & $\begin{array}{l}\text { Korean } \\
\text { Style }\end{array}$ & Average & $\begin{array}{l}\text { Standard } \\
\text { Deviation }\end{array}$ \\
\hline Lighting (GWh) & 7.7 & 7.7 & 7.7 & 7.7 & 7.7 & 7.7 & $7.7(12 \%)$ & $0(0 \%)$ \\
\hline Interior Equipment (GWh) & 42.2 & 42.1 & 42.2 & 42.2 & 42.2 & 42.2 & $42.2(68 \%)$ & $0(0 \%)$ \\
\hline Space heating $(\mathrm{GWh})$ & 1.2 & 0.9 & 1.1 & 1.3 & 1.4 & 1.2 & $1.2(2 \%)$ & $0.2(13 \%)$ \\
\hline Space cooling (GWh) & 11.3 & 11.2 & 11.5 & 11.3 & 11.3 & 11.4 & $11.3(18 \%)$ & $0.1(0.8 \%)$ \\
\hline $\begin{array}{l}\text { Total consumption } \\
\text { electricity }(\mathrm{GWh})\end{array}$ & 62.4 & 62.0 & 62.5 & 62.6 & 62.6 & 62.5 & 62.4 & $0.2(0.3 \%)$ \\
\hline $\begin{array}{l}\text { Unit floor electricity } \\
\text { consumption }\left(\mathrm{kWh} \cdot \mathrm{m}^{-1}\right)\end{array}$ & 337 & 336 & 338 & 338 & 338 & 338 & 337 & $1.0(0.3 \%)$ \\
\hline
\end{tabular}



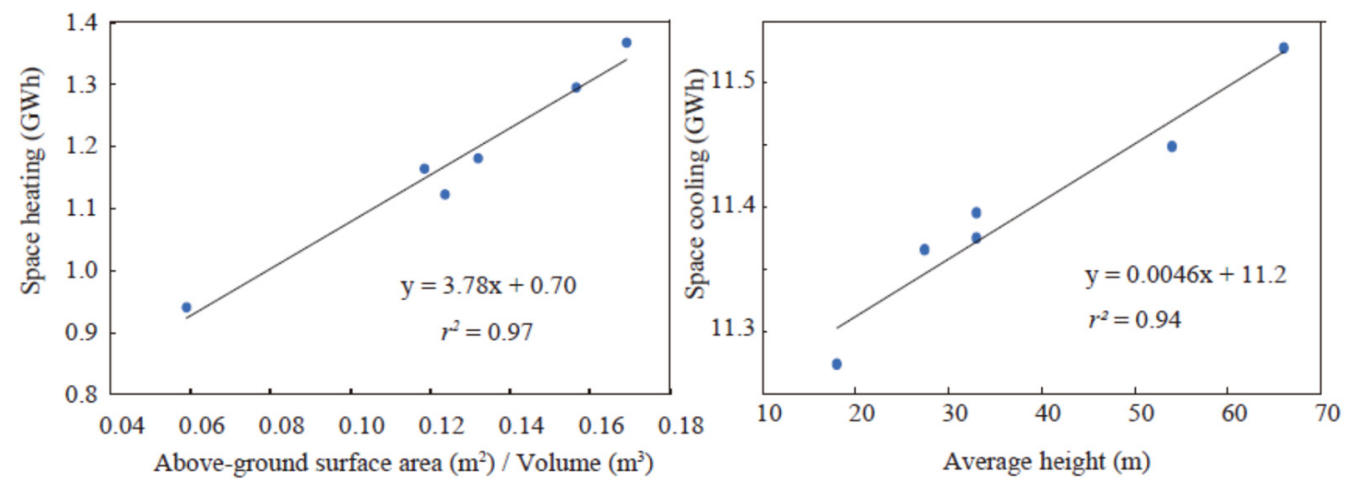

Figure 7. Influences of surface area/volume ratios and building heights on space heating (left) and cooling (right), respectively.

Space cooling is the second largest demand and shows clear relationship with outside temperatures from April to November (Figure 3). On the other hand, demand for space heating is so small that its correlation with out-side temperature in winter is not clear (Figure 3). Total energy demands show clear weekly cycles (national holidays are not considered) (Figure 3). Lighting and interior equipment do not have seasonal changes. Estimated hourly total demands for all the scenarios are highly correlated $(r>0.99)$ with that of the existing buildings (scenarios 0 ) as high demand components (i.e., interior equipment, lighting, and space cooling) do not show differences between the scenarios.

To investigate the impacts of shading, we conducted a test "with shades" and "without shades" for the building \# 8 in the existing buildings (scenario 0; Figure 6). The shades were produced by the building \# 9 , which is the tallest building in all the buildings considered and located south of the building \# 8 (Figure 6). The analysis was conducted in the same way for the scenario analyses for one year in an hourly resolution. Results show that the influence of shades are negligible in terms of the total annual energy demand (Table 4). However, the demand for space heating increases by shades by $5.7 \%$, but the demand for space cooling reduces by $0.5 \%$ (Table 4 ). As absolute numbers are similar between demands for space heating and cooling but with opposite signs, they cancel each other with little change in the total (Table 4). Therefore, we conclude that shading has little influence on the total building energy demands in the settings we considered.

Table 4. Influences of shades on building energy demand of building \# 8 of scenario 0 . Parentheses for "shaded" and "no shade" are ratios to the total. Parentheses for "difference" are ratios with "no shade". "Difference" is calculated as "Shaded"_"No shade".

\begin{tabular}{cccc}
\hline & Shaded (\%) & No Shade (\%) & Difference (\%) \\
\hline Space heating (MWh) & $104.3(1.8)$ & $98.7(1.7)$ & $5.6(5.7 \%)$ \\
Space cooling (MWh) & $1065.4(18.2)$ & $1071.2(18.3)$ & $-5.8(-0.5 \%)$ \\
Interior lighting (MWh) & $725.7(12.4)$ & $725.7(12.4)$ & $0(0.0 \%)$ \\
Interior equipment (MWh) & $3955.3(67.6)$ & $3955.3(67.6)$ & $0(0.0 \%)$ \\
Total (MWh) & $5850.7(100.0)$ & $5850.9(100.0)$ & $-0.2(0.0 \%)$ \\
\hline
\end{tabular}

\subsection{Technoeconomic Analysis with Rooftop PV Systems}

Building integrated PV (BIPV) are increasingly important for urban decarbonization when costs of PV systems are declining and land areas for PV are limited such as for Japan. However, BIPV potential for buildings in urban environment are affected by building forms and relationships between neighboring buildings for available sunlight (Figure 4). Analyses on existing buildings show that $81 \%$ of the rooftop area can receive more than $90 \%$ of the maximum solar radiation (Table 5). On the other hand, southern faced façade with no shades receives only $60-70 \%$ of the maximum solar radiation. As the cost of installation of rooftop PV systems are lower than that for facades [43], the first priority should be given to the rooftop, but newly developing PV materials with light weight such as perovskite PV 
could allow future application on façade more economic and easier than at present. All other scenarios have constant heights for all the buildings such that the rooftops of these buildings receive the maximum solar radiation.

Table 5. Radiation analysis on the existing buildings (scenario 0; Figure 4). Top and bottom represent ranges of annual radiation received on meshes. "\% of max radiation" indicates percentage of the maximum annual radiation $\left(1383 \mathrm{kWh} \cdot \mathrm{m}^{-2}\right)$. Rooftop and façade areas are percentages of the total areas. For example, $81 \%$ of the rooftop area received more than $90 \%$ of the maximum annual radiation.

\begin{tabular}{|c|c|c|c|c|}
\hline Top $\left(k W h \cdot m^{-2}\right)$ & $\begin{array}{c}\text { Bottom } \\
\left(\mathrm{kWh} \cdot \mathrm{m}^{-2}\right)\end{array}$ & $\begin{array}{l}\% \text { of Max } \\
\text { Radiation }\end{array}$ & $\begin{array}{c}\text { Rooftop Area } \\
(\%)\end{array}$ & Façade Area (\%) \\
\hline 1383 & 1244 & 90 & 81 & 0 \\
\hline 1383 & 1106 & 80 & 91 & 0 \\
\hline 1383 & 968 & 70 & 96 & 0 \\
\hline 1383 & 830 & 60 & 98 & 10 \\
\hline 1383 & 691 & 50 & 100 & 19 \\
\hline 1383 & 553 & 40 & 100 & 51 \\
\hline 1383 & 415 & 30 & 100 & 56 \\
\hline 1383 & 277 & 20 & 100 & 60 \\
\hline 1383 & 138 & 10 & 100 & 78 \\
\hline 1383 & 0 & 0 & 100 & 100 \\
\hline
\end{tabular}

As total rooftop areas are variable between the scenarios, amounts of PV generation is highly variable (Table 2). "Low-rise" buildings (scenario 1) have the largest rooftop area and PV capacity (4.4 MW) installed. Annual PV generation is $5.53 \mathrm{GWh}$, which supplies $8.9 \%$ of demand (Table 5). As the PV generation is small compared with the building demands, all PV generated electricity is consumed on-site (100\% self-consumption) for all the scenarios (Table 6). Thus, self-sufficiency and energy sufficiency are equal. In addition, as $\mathrm{CO}_{2}$ emission reduction is equal to the amount of grid electricity replaced by PV electricity, the values for $\mathrm{CO}_{2}$ emission reduction are the same with self-sufficiency and energy-sufficiency (Table 6). The situation is highly different when it is compared with residential houses where rooftop PV generation often exceed household demands [25].

Table 6. Energy indicators for 2018 and 2030. Results are the same for both years as optimal PV capacities are the same for both years. $70 \%$ of the rooftop area is used for the maximum PV installation.

\begin{tabular}{ccccccc}
\hline 2018 and 2030 & S0 & S1 & S2 & S3 & S4 & S5 \\
\hline Rooftop PV generation & 3.63 & 5.53 & 1.51 & 3.02 & 3.02 & 1.85 \\
$\quad\left(\mathrm{GWh}_{\mathrm{yr}}{ }^{-1}\right.$ ) & 5.8 & 8.9 & 2.4 & 4.8 & 4.8 & 3.0 \\
Self-sufficiency (\%) & 100 & 100 & 100 & 100 & 100 & 100 \\
Self-consumption (\%) & 5.8 & 8.9 & 2.4 & 4.8 & 4.8 & 3.0 \\
Energy sufficiency (\%) & 5.8 & 8.9 & 2.4 & 4.8 & 4.8 & 3.0 \\
$\mathrm{CO}_{2}$ emission reduction & &
\end{tabular}

If PV are installed on the façade receiving greater than $50 \%\left(691 \mathrm{kWh} \cdot \mathrm{m}^{-2}\right)$ of the maximum solar insolation for the existing buildings, the corresponding façade area is $12,425 \mathrm{~m}^{2}$ (19\% of the total façade area including windows) and the façade PV is expected to generate annually $2.1 \mathrm{GWh}$ of electricity, which is about the same amount with the annual rooftop PV generation, emphasizing the need to utilize the façade to further increase on-site PV generation.

Rapidly declining cost of PV system creates increasing opportunities for affordable decarbonization of buildings with BIPV. For 2018, LCOE of $0.13 \$ \cdot \mathrm{kWh}^{-1}$ is slightly lower than high-voltage electricity price of $0.15 \$ \cdot \mathrm{kWh}^{-1}$, indicating that rooftop PV is already economic in 2018 . As self-consumption is $100 \%$ for all the scenarios, simple payback period are the same values for all the scenarios. Payback period is 14 years in 2018, which is still longer than generally considered promising investment opportunities of less than 
10 years [44]. Cost saving is less than $1 \%$, which indicates difficulty to motivate building owners to invest on on-site PV systems in 2018. By 2030, economic situations of rooftop PV for these buildings improve significantly. LCOE becomes $0.07 \$ \cdot \mathrm{kWh}^{-1}$, which is half of the tariff price. Payback period of 6 years is less than half of that of 2018. However, cost saving for energy expense is only $1-3 \%$ owing smaller PV generation in comparison to the demand. NPVs in 2030 become nearly four times larger than that in 2018. The maximum NPV reaches $\$ 7.0$ million for the low-rise buildings (scenario 1), which is 3.7 times larger than that for the high-rise building (Table 7).

Table 7. Financial indicators of rooftop PV systems for 2018 and 2030.

\begin{tabular}{ccccccc}
\hline $\mathbf{2 0 1 8}$ & S0 & S1 & S2 & S3 & S4 & S5 \\
\hline LCOE $\left(\$ \cdot \mathrm{kWh}^{-1}\right)$ & 0.13 & 0.13 & 0.13 & 0.13 & 0.13 & 0.13 \\
NPV (million \$) & 1.21 & 1.85 & 0.50 & 1.00 & 1.00 & 0.62 \\
Payback period $(\mathrm{yr})$ & 14 & 14 & 14 & 14 & 14 & 14 \\
Cost saving $(\%)$ & 0.5 & 0.8 & 0.2 & 0.4 & 0.4 & 0.3 \\
\hline 2030 & $\mathrm{S} 0$ & $\mathrm{~S} 1$ & $\mathrm{~S} 2$ & $\mathrm{~S} 3$ & $\mathrm{~S} 4$ & $\mathrm{~S} 5$ \\
\hline LCOE $\left(\$ \cdot \mathrm{kWh}^{-1}\right)$ & 0.07 & 0.07 & 0.07 & 0.07 & 0.07 & 0.07 \\
NPV (million \$) & 4.60 & 7.00 & 1.91 & 3.82 & 3.82 & 2.33 \\
Payback period $(\mathrm{yr})$ & 6 & 6 & 6 & 6 & 6 & 6 \\
Cost saving $(\%)$ & 2.0 & $3 . \%$ & 0.8 & 1.6 & 1.6 & 1.0 \\
\hline
\end{tabular}

\section{Discussion}

In fall 2020, Japanese government declared a goal to reach carbon neutral by 2050, which substantially changed social atmosphere toward carbon neutrality. Primary sources of carbon-free energy will be renewable energies, in particular, "solar power" [45]. As available lands for PV installation are limited in Japan and for the sake of saving natural lands [46], it is critical to maximize the rooftop uses for PV generation in a physically maximum extent. Although feed-in-tariffs (FITs) helped successfully expand PV in Japan [47], rooftop PVs of large buildings have received little attention as rooftop PV generation is rather small compared to large building demands. As our analyses indicated, declining cost of PV systems for the next decades will create large economic benefits to install PV on the rooftops of large buildings. In addition, total rooftop areas of large buildings in cities are not negligible and difficult to be replaced on the ground. Therefore, it is important to place adequate policy measures to facilitate expansion of rooftop PV systems on large buildings.

A few relevant policies can be recommended in this regard. First, current building form regulations mainly through FAR and BCR could be upgraded to promote the installation of rooftop PV on new buildings. One measure is to introduce a performance-based regulation under the designated FAR where energy efficiency is set as one of the core performances mandated to buildings. Another measure is to craft a form-based regulation designating wall setbacks, maximum height, minimum "Roof Area Ratio", etc. to facilitate building forms that allow effective rooftop PV installation. Second, in Japan where population and economy are shrinking in many cities, it is possible to reduce the designated FAR in existing urban area, which will prevent the construction of high-rise buildings that have less opportunities to install rooftop PV. However, this measure should be carefully discussed in relation to the compact city-plus-network concept that promotes high density urban area to reduce energy consumption in transport sector.

Toward carbon neutrality, critical measure for buildings are energy efficiency improvements including electrification [48]. Lighting, electric equipment, space cooling and heating have large potentials to reduce energy consumption but providing the same or better services by switching to more efficient and smart apparatus [49]. Passive solutions also play important roles particularly during building design phases, which are, for example, building materials for thermal insulation, building forms, window-to-wall ratio leading to reduced energy consumption. However, building design should be considered not solely 
from the energy efficiency requirement but also from other perspectives including the livability inside the building and the quality of environment outside building [12]. Buildings also need to prepare for adaptation to increasing climate change by enhancing resilience, etc., which often overlaps with mitigation measures such as developing decentralized energy systems [50].

In a city scale, rooftop PVs coupled with electric vehicles (EV) are possibly highly effective tools to decarbonize urban energy systems $[5,6]$. EVs are important means to decarbonize transport sector by replacing internal combustion of fossil fuels with electricity, but also play roles as energy storage for VRE such as rooftop PVs [25] or wind power [51]. It has been shown that rooftop PVs combined with EVs in a city scale can supply up to $95 \%$ of electricity to cities in Japan [6]. In the case of the special districts of Tokyo including Shinagawa, the PV plus EV systems can supply $53 \%$ of the annual demands. As large buildings of the central urban area such as this study consumes all the on-site PV generation, EVs or batteries have no roles to play as energy storage. However, Tokyo has various types of districts with independent houses and small buildings with smaller demands. Rooftop PVs of these buildings produce excess electricity, which supplies part of the demands of the large buildings by coupling with EVs. To fully understand the supply and demand balance of urban power systems, it is necessary to analyze disaggregated rooftop PV generation coupled with EVs within cities considering grid constrains.

\section{Conclusions}

This study established a workflow of assessing waterfront office building redevelopment plans with rooftop photovoltaics (PV), different building shapes and arrangements. We produced five scenarios in comparison to existing buildings with the same floor area ratio (FAR) and total floor areas. Demands for space heating are found to strongly correlate with surface area to volume ratio, although space heating demand for buildings are small in comparison to the total demand of buildings for the cases we considered. Shades by neighboring buildings affect space heating and cooling demands in opposite signs and cancel each other. Therefore, shades have little influence on the total energy demand for the buildings. Rooftop PV is already economic in 2018, and by 2030 it improves substantially with payback periods reaching 6 years. However, the rooftop PV contribution on the total demands of buildings or $\mathrm{CO}_{2}$ emission reduction is small (2-9\%), as rooftop areas are limited on the large buildings. It is noted that places such as Japan where lands are limited for PV installation, should implement mandatory regulation of installing rooftop PVs on buildings as such investments should not be issues for building owners. In addition, it is recommended to upgrade building form regulation to promote the installation of rooftop PV on new buildings.

Author Contributions: Conceptualization, Y.C. and T.K.; methodology, Y.C. and T.K.; investigation, Y.C. and T.K., writing - original draft, Y.C., T.K. and A.M.; validation, T.K.; formal analysis, T.K.; investigation, T.K.; software, T.K.; writing-review and editing, T.K.; visualization, T.K.; supervision, T.K.; funding acquisition, Y.Y. All authors have read and agreed to the published version of the manuscript.

Funding: This research received no external funding.

Data Availability Statement: Data to this article can be found online at: https:/ / doi.org/10.17632 /wfpkdc6rd7.1 (accessed on 5 January 2022).

Acknowledgments: We appreciate Soowon Chang at Purdue University for sharing Grasshopper files for the building energy analyses.

Conflicts of Interest: The authors declare no conflict of interest. 


\section{References}

1. United Nations Human Settlements Programme. Cities and Climate Change: Global Report on Human Settlements, 2011; Routledge: London, UK, 2011.

2. Dodman, D. Blaming cities for climate change? An analysis of urban greenhouse gas emissions inventories. Environ. Urban. 2009, 21, 185-201. [CrossRef]

3. Nam, T.; Pardo, T.A. Smart city as urban innovation: Focusing on management, policy, and context. In Proceedings of the 5th International Conference on Theory and Practice of Electronic Governance, Tallin, Estonia, 26-28 September 2011; pp. 185-194. [CrossRef]

4. Kobashi, T.; Yamagata, Y.; Yoshida, T.; Chang, S.; Mochizuki, Y.; Ahl, A.; Aleksejeva, J. Chapter 9—Smart city and ICT infrastructure with vehicle to $X$ applications toward urban decarbonization. In Urban Systems Design; Yamagata, Y., Yang, P.P.J., Eds.; Elsevier: Amsterdam, The Netherlands, 2020; pp. 289-333. ISBN 978-0-12-816055-8.

5. Kobashi, T.; Yoshida, T.; Yamagata, Y.; Naito, K.; Pfenninger, S.; Say, K.; Takeda, Y.; Ahl, A.; Yarime, M.; Hara, K. On the potential of "Photovoltaics + Electric vehicles" for deep decarbonization of Kyoto's power systems: Techno-economic-social considerations. Appl. Energy 2020, 275, 115419. [CrossRef]

6. Kobashi, T.; Jittrapirom, P.; Yoshida, T.; Hirano, Y.; Yamagata, Y. SolarEV City concept: Building the next urban power and mobility systems. Environ. Res. Lett. 2021, 16, 024042. [CrossRef]

7. Chen, Y. Financialising urban redevelopment: Transforming Shanghai's waterfront. Land Use Policy 2020, 112, 105126. [CrossRef]

8. Papatheochari, T.; Coccossis, H. Development of a waterfront regeneration tool to support local decision making in the context of integrated coastal zone management. Ocean Coast. Manag. 2019, 169, 284-295. [CrossRef]

9. Keyvanfar, A.; Shafaghat, A.; Mohamad, S.; Abdullahi, M.M.; Ahmad, H.; Derus, N.H.M.; Khorami, M. A sustainable historicwaterfront revitalization decision support tool for attracting tourists. Sustainability 2018, 10, 215. [CrossRef]

10. ECCJ. Features of Office Building Energy Consumption. Available online: https://www.eccj.or.jp/office_bldg/01.html (accessed on 13 August 2021).

11. Naboni, E.; Natanian, J.; Brizzi, G.; Florio, P.; Chokhachian, A.; Galanos, T.; Rastogi, P. A digital workflow to quantify regenerative urban design in the context of a changing climate. Renew. Sustain. Energy Rev. 2019, 113, 109255. [CrossRef]

12. Natanian, J.; Aleksandrowicz, O.; Auer, T. A parametric approach to optimizing urban form, energy balance and environmental quality: The case of Mediterranean districts. Appl. Energy 2019, 254, 113637. [CrossRef]

13. Han, T.; Huang, Q.; Zhang, A.; Zhang, Q. Simulation-based decision support tools in the early design stages of a green building-A review. Sustainability 2018, 10, 3696. [CrossRef]

14. Chang, S.; Saha, N.; Castro-Lacouture, D.; Yang, P.P.J. Multivariate relationships between campus design parameters and energy performance using reinforcement learning and parametric modeling. Appl. Energy 2019, 249, 253-264. [CrossRef]

15. Chang, S.; Castro-Lacouture, D.; Yamagata, Y. Decision support for retrofitting building envelopes using multi-objective optimization under uncertainties. J. Build. Eng. 2020, 32, 101413. [CrossRef]

16. Chen, Y.; Hong, T.; Piette, M.A. Automatic generation and simulation of urban building energy models based on city datasets for city-scale building retrofit analysis. Appl. Energy 2017, 205, 323-335. [CrossRef]

17. Li, W.; Zhou, Y.; Cetin, K.; Eom, J.; Wang, Y.; Chen, G.; Zhang, X. Modeling urban building energy use: A review of modeling approaches and procedures. Energy 2017, 141, 2445-2457. [CrossRef]

18. Johari, F.; Peronato, G.; Sadeghian, P.; Zhao, X.; Widén, J. Urban building energy modeling: State of the art and future prospects Renew. Sustain. Energy Rev. 2020, 128, 109902. [CrossRef]

19. Ferrando, M.; Causone, F.; Hong, T.; Chen, Y. Urban building energy modeling (UBEM) tools: A state-of-the-art review of bottom-up physics-based approaches. Sustain. Cities Soc. 2020, 62, 102408. [CrossRef]

20. Natanian, J.; Auer, T. Beyond nearly zero energy urban design: A holistic microclimatic energy and environmental quality evaluation workflow. Sustain. Cities Soc. 2020, 56, 102094. [CrossRef]

21. Zhang, J.; Xu, L.; Shabunko, V.; Tay, S.E.R.; Sun, H.; Lau, S.S.Y.; Reindl, T. Impact of urban block typology on building solar potential and energy use efficiency in tropical high-density city. Appl. Energy 2019, 240, 513-533. [CrossRef]

22. Li, Y.; Liu, C. Techno-economic analysis for constructing solar photovoltaic projects on building envelopes. Build. Environ. 2018, 127, 37-46. [CrossRef]

23. Hoppmann, J.; Volland, J.; Schmidt, T.S.; Hoffmann, V.H. The economic viability of battery storage for residential solar photovoltaic systems-A review and a simulation model. Renew. Sustain. Energy Rev. 2014, 39, 1101-1118. [CrossRef]

24. BNEF. New Energy Outlook 2018; BNEF: London, UK, 2018.

25. Kobashi, T.; Say, K.; Wang, J.; Yarime, M.; Wang, D.; Yoshida, T.; Yamagata, Y. Techno-economic assessment of photovoltaics plus electric vehicles towards household-sector decarbonization in Kyoto and Shenzhen by the year 2030. J. Clean. Prod. 2020, 253, 119933. [CrossRef]

26. Wilkinson, S.; John, M.; Morrison, G.M. Rooftop PV and the renewable energy transition; a review of driving forces and analytical frameworks. Sustainability 2021, 13, 5613. [CrossRef]

27. Zhou, Y.; Cao, S.; Hensen, J.L.M. An energy paradigm transition framework from negative towards positive district energy sharing networks-Battery cycling aging, advanced battery management strategies, flexible vehicles-to-buildings interactions, uncertainty and sensitivity analysis. Appl. Energy 2021, 288, 116606. [CrossRef] 
28. Say, K.; Schill, W.P.; John, M. Degrees of displacement: The impact of household PV battery prosumage on utility generation and storage. Appl. Energy 2020, 276, 115466. [CrossRef]

29. Lang, T.; Ammann, D.; Girod, B. Profitability in absence of subsidies: A techno-economic analysis of rooftop photovoltaic self-consumption in residential and commercial buildings. Renew. Energy 2016, 87, 77-87. [CrossRef]

30. Blair, N.; Diorio, N.; Freeman, J.; Gilman, P.; Janzou, S.; Neises, T.W.; Wagner, M.J. System Advisor Model (SAM) General Description; National Renewable Energy Laboratory: Golden, CO, USA, 2018.

31. Booth, B.; Mitchell, A. Getting Started with ArcGIS GIS by ESRI; ESRI: Redlands, CA, USA, 2001; p. 260.

32. Geospatial Information Authority of Japan. Fundamental Geospatial Data. Available online: https://fgd.gsi.go.jp/download/ menu.php (accessed on 5 March 2020).

33. Roudsari, M.S.; Pak, M. Ladybug: A parametric environmental plugin for grasshopper to help designers create an environmentallyconscious design. In Proceedings of the BS2013: 13TH Conference of International Building Performance Simulation Association, Chambery, France, 26-28 August 2013; pp. 3128-3135.

34. Crawley, D.B.; Lawrie, L.K.; Winkelmann, F.C.; Buhl, W.F.; Huang, Y.J.; Pedersen, C.O.; Strand, R.K.; Liesen, R.J.; Fisher, D.E.; Witte, M.J.; et al. EnergyPlus: Creating a new-generation building energy simulation program. Energy Build. 2001, 33, 319-331. [CrossRef]

35. EnergyPlus. Testing and Validation. Available online: https:/ / energyplus.net/testing (accessed on 3 June 2021).

36. King, A. SIREN: SEN's interactive renewable energy network tool. In Transition towards 100\% Renewable Energy; Sayigh, A., Ed.; Springer: Cham, Switzerland, 2018; p. 536, ISBN 978-3-319-69844-1.

37. An, H.J.; Yoon, J.H.; An, Y.S.; Heo, E. Heating and cooling performance of office buildings with a-Si BIPV windows considering operating conditions in temperate climates: The case of Korea. Sustainability 2018, 10, 4856. [CrossRef]

38. Short, W.; Packey, D.J.; Holt, T. A Manual for the Economic Evaluation of Energy Efficiency and Renewable Energy Technologies. Available online: https:/ / www.nrel.gov/docs/legosti/old/5173.pdf (accessed on 13 August 2020).

39. Joshi, K.K.; Kono, T. Optimization of floor area ratio regulation in a growing city. Reg. Sci. Urban Econ. 2009, 39, 502-511. [CrossRef]

40. Usui, H. Variation in Building Heights under Zoning Regulations of Building Coverage Ratio and Floor Area Ratio: Theoretical. In Proceedings of the ISUF 2020 Virtual Conference Proceedings, Virtual, 23 February 2020.

41. BEMA. 43rd Report on Building Energy Consumption (2019-2020). Available online: http://www.bema.or.jp/_src/11317/ digest43.pdf?v=1627864413127 (accessed on 15 August 2021).

42. Arakawa, S.; Kuboi, D.; Yoshizawa, A.; Naraoka, S. Actual condition survey on energy consumption in office buildings for energy saving. Techinical Pap. Annu. Meet. Soc. Heat. Air-Cond. Sanit. Eng. 2016, 8, 73-76.

43. SUPSI. Building Integrated Photovoltaics: A Practical Handbook for Solar Buildings' Stakeholders; Status Report; SUPSI-Swiss BIPV Competence Centre: Manno, Switzerland, 2020.

44. Li, H.X.; Zhang, Y.; Li, Y.; Huang, J.; Costin, G.; Zhang, P. Exploring payback-year based feed-in tariff mechanisms in Australia. Energy Policy 2021, 150, 112133. [CrossRef]

45. METI. Summary for Basic Energy Plan of Japan (Draft). Available online: https://www.enecho.meti.go.jp/committee/council/ basic_policy_subcommittee/2021/046/046_004.pdf (accessed on 16 August 2021).

46. Kim, J.Y.; Koide, D.; Ishihama, F.; Kadoya, T.; Nishihiro, J. Current site planning of medium to large solar power systems accelerates the loss of the remaining semi-natural and agricultural habitats. Sci. Total Environ. 2021, 779, 146475. [CrossRef]

47. Cozzi, L.; Gould, T.; Bouckart, S.; Crow, D.; Kim, T.-Y.; McGlade, C.; Olejarnik, P.; Wanner, B.; Wetzel, D. World Energy Outlook 2020; OECD Publishing: Paris, France, 2020; Volume 2050, pp. 1-461.

48. Belussi, L.; Barozzi, B.; Bellazzi, A.; Danza, L.; Devitofrancesco, A.; Fanciulli, C.; Ghellere, M.; Guazzi, G.; Meroni, I.; Salamone, F.; et al. A review of performance of zero energy buildings and energy efficiency solutions. J. Build. Eng. 2019, 25, 100772. [CrossRef]

49. Lovins, A. Reinventing Fire: Bold Business Solutions for the New Energy Era; Chelsea Green Publishing: Hartford, VT, USA, 2011.

50. Economidou, M.; Todeschi, V.; Bertoldi, P.; D’Agostino, D.; Zangheri, P.; Castellazzi, L. Review of 50 years of EU energy efficiency policies for buildings. Energy Build. 2020, 225, 110322. [CrossRef]

51. Lund, H.; Kempton, W. Integration of renewable energy into the transport and electricity sectors through V2G. Energy Policy 2008, 36, 3578-3587. [CrossRef] 